\title{
Ammopemphix hemisphaericus sp. nov., a new attached agglutinated foraminifer from the Pleistocene of the Arctic Ocean, and the taxonomic status of the genus Ammopemphix Loeblich, 1952
}

\author{
Anna Waśkowska ${ }^{1}$ D Michael A. Kaminski ${ }^{2}$
}

Received: 21 March 2018 / Accepted: 15 May 2018 / Published online: 4 June 2018

(c) The Author(s) 2018

\begin{abstract}
The new species Ammopemphix hemisphaericus sp. nov. is described from Pleistocene sediments of the Central Arctic Ocean. The species is a finely agglutinated monothalamous form with hemispherical shape and a terminal aperture located at the top of the test, often occurring in pseudocolonies. A. hemisphaericus sp. nov. attaches itself to inorganic or organic substrates, often growing attached to the inside surfaces of calcareous or agglutinated foraminiferal tests. Pseudocolonies of A. hemisphaericus sp. nov. may also attach themselves to previous generations of Ammopemphix individuals. Based on our study of numerous specimens of Ammopemphix from the Central Arctic Ocean, we propose modifications to the description of the genus. The genus may be pseudocolonial or consist of isolated individuals, and in the case of pseudocolonial forms, individual specimens may be arranged randomly or symmetrically. The genus Ammopemphix is found mostly in polar regions, and is here reported for the first time from the fossil record.
\end{abstract}

Keywords Agglutinated foraminifera - Arctic Ocean · Pleistocene

\section{Introduction}

The glacial environment of the deep Arctic Ocean yields species that are predisposed to life in cold and oligotrophic conditions. Because of profound changes in sea-ice cover, surface productivity, and sedimentation linked to glacial/interglacial cycles, the benthic foraminiferal and ostracode assemblages found in the glacial Arctic Ocean are much less abundant and diverse than in the interglacial faunas [2]. Glacial assemblages reported from sediment cores are sparse and typically only consist of a few species of agglutinated forms [6, 7, 13].

During the summer of 2014, four long kastenlot cores and 36 gravity cores were collected on the Lomonosov Ridge during Expedition 87 of the R/V Polarstern. The Pleistocene foraminiferal assemblages from these cores consist of

Anna Waśkowska

waskowsk@agh.edu.pl

1 Faculty of Geology, Geophysics and Environmental Protection, AGH University of Science and Technology, al. Mickiewicza 30, 30-059 Kraków, Poland

2 Geosciences Department, College of Petroleum Engineering and Geosciences, King Fahd University of Petroleum and Minerals, PO Box 701, Dhahran 31261, Saudi Arabia approximately 20 species of agglutinated foraminifera [13]. The taxonomy and biostratigraphy of the benthic foraminiferal assemblages from the PS87 cores will be described separately. The purpose of this paper is to describe an enigmatic new species that lives attached to sediment particles, or most often to fragments of other specimens of agglutinated foraminifera.

The genus Ammopemphix has been previously reported from the Arctic and Antarctic seas [e.g., 3, 14, 15, 17, 24], but specimens from the Lomonosov Ridge display morphological characteristics that are not known among the previously described species. In this study we describe a new species of Ammopemphix and modify the current definition of the genus.

\section{Materials and methods}

The sediment cores from which the new species is described were collected from the Lomonosov Ridge in the Central Arctic Ocean during Expedition PS87 of the R/V Polarstern in the summer of 2014 [12]. The new species is described from Kastenlot Core PS87/30-1 (coordinates: $88^{\circ} 39.72^{\prime} \mathrm{N}$, $61^{\circ} 32,52^{\prime} \mathrm{W}$, water depth $1276.8 \mathrm{~m}$ ); Kastenlot Core PS87/023- 1 corecatcher (coordinates: $86^{\circ} 38.23^{\prime} \mathrm{N}, 44^{\circ}$ 
53.98' W, water depth $2444.8 \mathrm{~m})$, Gravity Core PS87/100 corecatcher (coordinates: $81^{\circ} 21.42^{\prime} \mathrm{N}, 142^{\circ} 35.46^{\prime} \mathrm{E}$, water depth $951 \mathrm{~m}$ ) and Gravity Core PS87/108-1 corecatcher (coordinates: $81^{\circ} 12.79^{\prime} \mathrm{N}, 141^{\circ} 10.70^{\prime} \mathrm{E}$, water depth $1439.6 \mathrm{~m})$. All these core locations are on the crest of the Lomonosov Ridge (Fig. 1). The sediment lithology is brown and dark brown silty clay, with interbedded sandy clay (Fig. 2). The studied agglutinated foraminifer-bearing interval in Core PS PS87/30-1 encompasses the middle Pleistocene between MIS4 and MIS19 [21].

Sediment cores were sampled onboard ship, typically every $10 \mathrm{~cm}$, and samples were gently washed through a $63 \mu \mathrm{m}$ sieve under running water. Samples of larger volume were collected from the core catchers. Residues were dried at $60{ }^{\circ} \mathrm{C}$, transferred into vials, and picked into cardboard slides under a binocular microscope. Specimens were photographed in the SEM Laboratory of the Faculty of Geology, Geophysics and Environmental Protection, AGH University of Science and Technology, Kraków.

\section{Systematic micropalaeontology}

\section{Order ASTRORHIZIDA Lankester, 1885}

Suborder HEMISPHAERAMMININAE Loblich \& Tappan, 1961
Superfamily PSAMMOSPHAEROIDEA Haeckel, 1894

Family LACUSTRINELLIDAE Mikhalevich, 1995

Genus Ammopemphix Loeblich, 1952

Ammopemphix hemisphaericus Waśkowska \& Kaminski, sp. nov.

(Fig. 3a-e; Fig. 4a-f; Fig. 5a-e)

Derivation of name From the hemispherical shape of the test.

Type specimens The holotype (EMRC 7/8x) and paratypes (EMRC 7/8x $-\mathrm{x}$ ) are archived in the collections of the European Micropalaeontological Reference Centre at Micropress Europe, Krakow, Poland, in Cabinet 7, Drawer 8.

Material More than 65 specimens, both as single individuals or in pseudocolonies consisting of several to more than a dozen individuals. Specimens were recovered from kastenlot Core PS87/030-1, Kastenlot Core PS87/023-1, corecatcher, Gravity Core PS87/100, corecatcher, and Gravity Core PS87/108-1, corecatcher.

Locality and horizon Lomonosov Ridge in the Central Arctic Ocean, Core PS87/30, 278-280 cm. Middle Pleistocene, MIS-10 according to Stein et al. [21].

Description Test monothalamous, attached, pseudocolonial. The chamber is hemispherical, planoconvex, with a flat attachment surface and a convex dorsal side. The attachment surface consists of a thin agglutinated wall with a smooth inner surface. Individuals are sometimes found as isolated
Fig. 1 The Lomonosov Ridge area with position of cores containing Ammopemphix hemisphaericus sp. nov

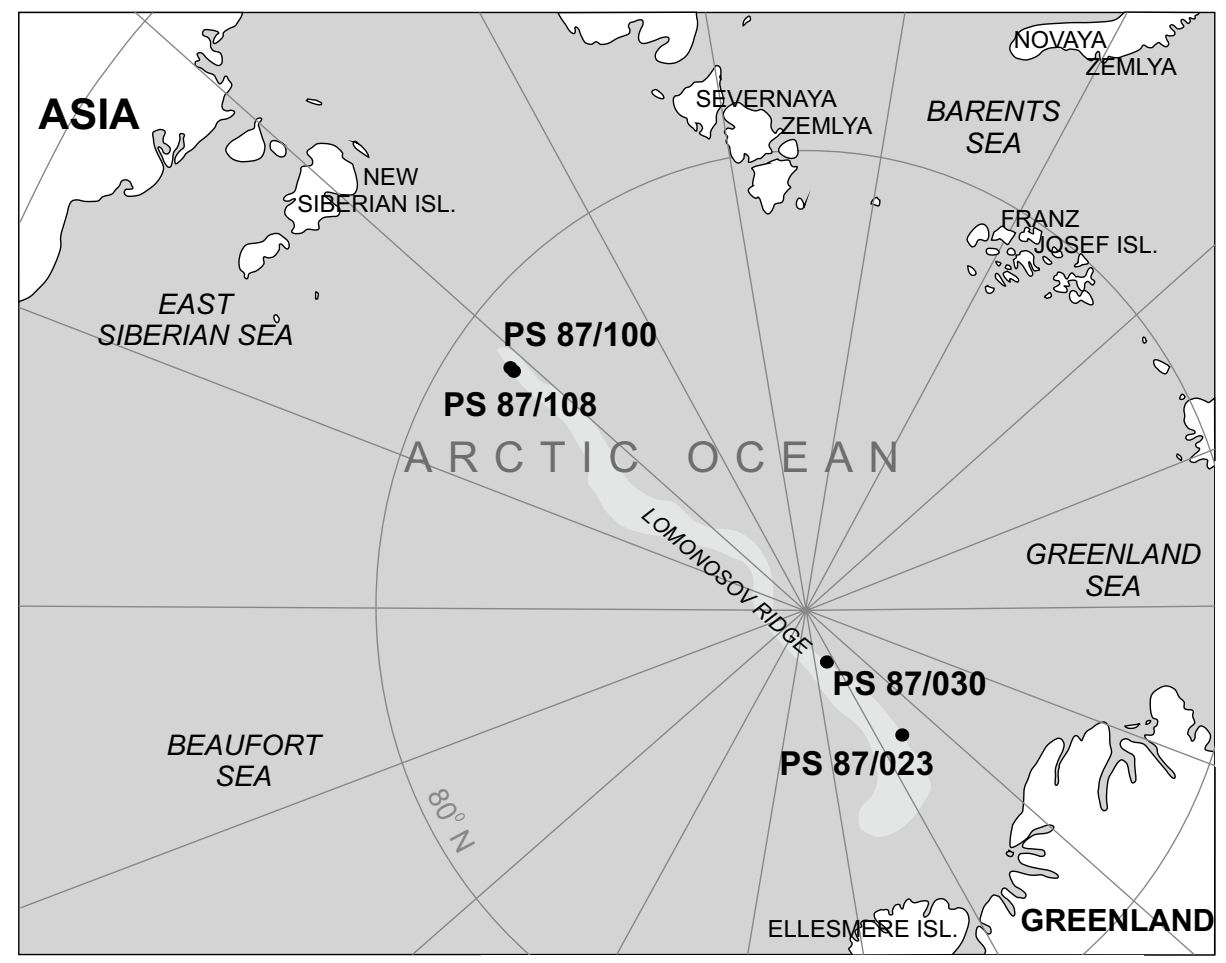


Fig. 2 Chronology and lithology of the type section Core PS87/30-1, after Stein et al. [21] with distribution of samples containing the holotype and paratypes Ammopemphix hemisphaericus sp. nov

\section{PS $87 / 030-1$}

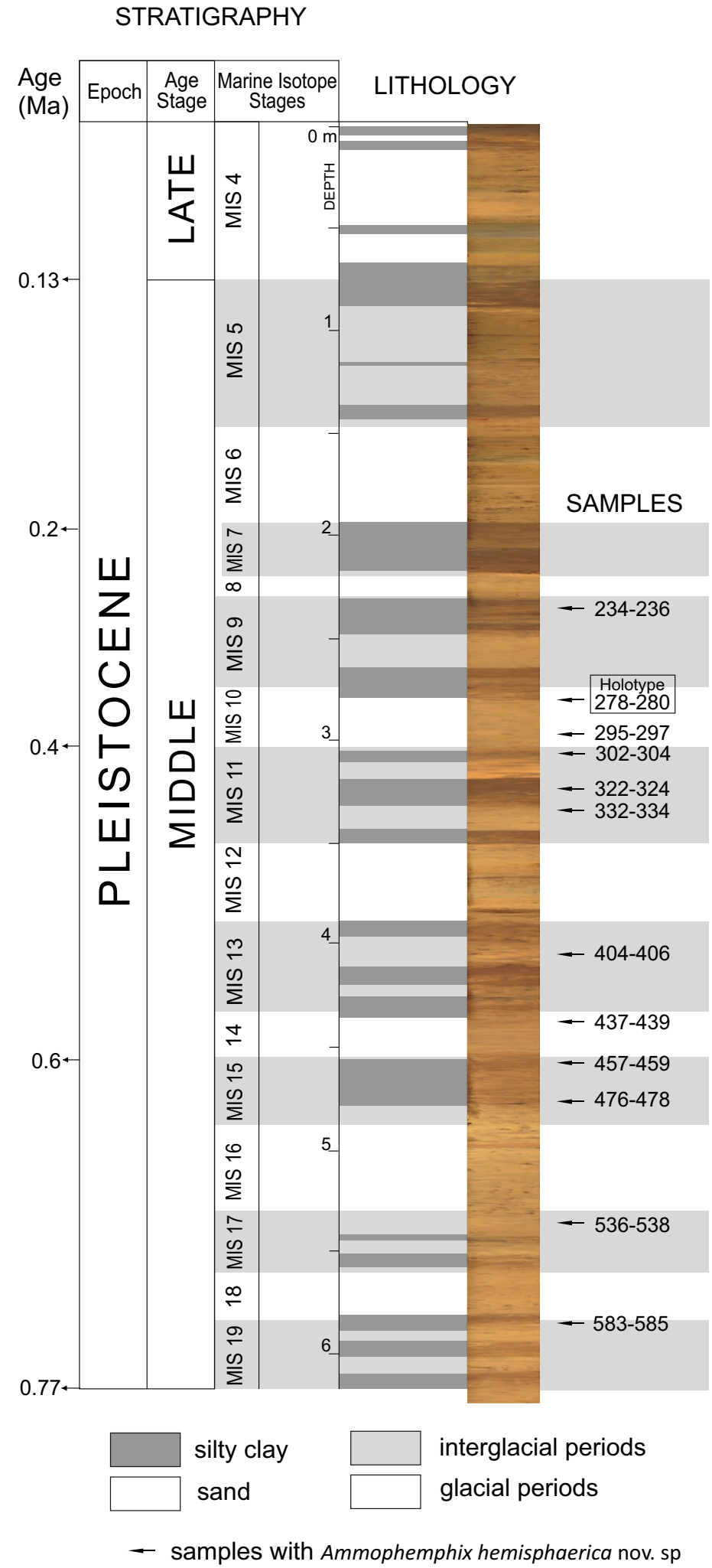




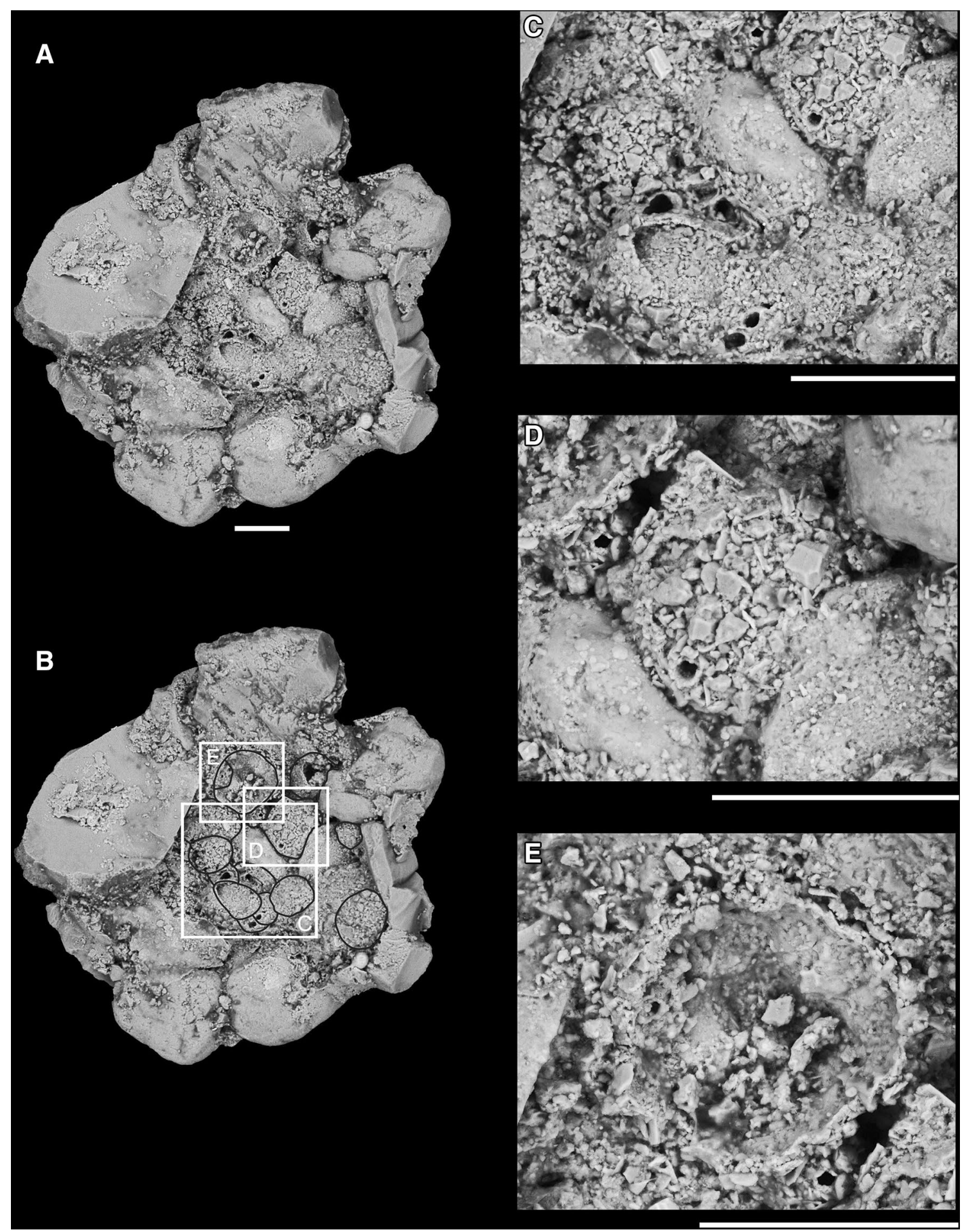

Fig. 3 Holotype specimen of Ammopemphix hemisphaericus sp. nov. attached to a fragment of an agglutinated test (Core PS87/30 278$280 \mathrm{~cm}$ ) (SEM photo). a General view of the pseudocolony, b position of individual photos (white squares) and outlines of individual specimens (highlighted with black lines), $\mathbf{c}$ details of a fragment of a pseudocolony with the holotype (upper right corner), d Ammopemphix hemisphaericus sp. nov. holotype (EMRC-7/x), e broken specimen of Ammopemphix hemisphaericus sp. nov.. showing the finely agglutinated interior, Scale bar $=100 \mu \mathrm{m}$ 
specimens, but more often the species forms pseudocolonies with individuals attached to one another, but without any connection between the individual tests. Test wall agglutinated, thin, made of small (ca. $10 \mu \mathrm{m})$ mineral grains in a yellowish-orange organic cement. Grain size of agglutinated grains is variable, with finer grains used in the interior of the test and around the aperture. Aperture single, simple, rounded, oval, or subtriangular, situated on a elevated collar on the dorsal side of the test.

Dimensions Holotype (Fig. 3c, d) is $90 \mu \mathrm{m}$ in diameter, $40 \mu \mathrm{m}$ high, with an aperture $5 \mu \mathrm{m}$ in diameter. Paratypes range from $20 \mu \mathrm{m}$ to $155 \mu \mathrm{m}$ in diameter.

Remarks Ammopemphix hemisphaericus sp. nov. belongs to one of the more commonly occurring agglutinated foraminiferal species in the Arctic Pleistocene. It can be found attaching itself to crevices and depressions on clastic and bioclastic mineral grains. It often occupies the interiors of other agglutinated foraminifera such as Psammosphaera, hemispherical fragments of Hemisphaerammina, or the concave surfaces of miscellaneous fragments derived from an undetermined agglutinated foraminifer. Specimens have also been observed on the interior of the bilamellar wall of a species that resembles Reophax davisii Parr, and on the interior of a tubular species belonging to the genus Psammosiphonella (Fig. 4c). More rarely, it occurs attached to a calcareous benthic foraminifer, a specimen of Neogloboquadrina, a bivalve shell fragment, or an ice-rafted quartz grain (Fig. 4d). Successive generations of A. hemisphaericus sp. nov. can be observed on a single substrate particlewhere younger forms attach themselves on top of (or inside) previous generations of Ammopemphix (Fig. 5b, d, e). In all cases the apertures of adjacent individuals open dorsally, indicating there was no foramen or other type of connection between the tests. Their habit of building new tests on/in those of previous generations implies that juveniles did not disperse widely after reproduction took place, and is likely related to their choice of a suitable substrate.

Concentrations of A. hemisphaericus sp. nov. form pseudocolonies in which individuals display different stages of development. Smaller hemispherical specimens are found among larger specimens that display well-developed apertures. Pseudocolonies may consist of several to more than a dozen individuals.

Ammopemphix hemisphaericus sp. nov. is a delicate form that is easily damaged. The aperture or the entire top of the specimen may be missing, and sometimes only the outline of basal attachment is seen on clastic grains.

The occurrence of A. hemisphaericus sp. nov. is variable at the Lomonosov Ridge sites. The species is more common in the interglacial layers of the sediment cores. The glacial layers only contain sporadic single occurrences, which testifies to the fact that its development was limited in the highly oligotrophic glacial environment, when the central Arctic was covered by thick ice.

\section{Discussion}

\section{The Pleistocene agglutinated foraminiferal assemblage}

Ammopemphix hemisphaericus sp. nov. is most often found in agglutinated foraminiferal assemblages that show elevated biodiversity. The Pleistocene assemblages are normally dominated by Reticulophragmium pusillum (Brady), with Haplophragmoides arcticus Kaminski, Waskowska and Chan, Trochammina lomonosovensis Evans and Kaminski, and the attached form Placopsinella aurantiaca Earland as subdominant or accompanying species. In samples with $A$. hemisphaericus $\mathrm{sp}$. nov. monothalamids are commonly represented by such forms as Psammosphaera, Saccammina, Hemisphaerammina, as well as agglutinated tubes, including Psammosiphonella, Rhizammina, and Hyperammina. The species Reophax davisii Paar, Pseudonodosinella nodulosa (Brady), Hormosina sp., Alvelophragmium polarensis O'Neill, Cystammina pauciloculata (Brady), and Glomospira gordialis (Jones and Parker) are rare elements of the assemblage. Some specimens of A. hemisphaericus sp. nov. are found attached to large, coarsely agglutinated fragments that show little or no curvature, which may be pieces of a larger agglutinated foraminifer such as a xenophyophore, but because of their fragmentary nature their taxonomic affinity is difficult to establish. In the upper two metres of the studied cores, the interglacial layers also contain calcareous benthic foraminifera dominated by Cassidulina and abundant planktonic foraminifera belonging to the genus Neogloboquadrina.

\section{The microhabitat and ecology of Ammopemphix}

Pseudocolonies of A. hemisphaericus sp. nov. are found on clastic substrates that are mainly of biogenic origin. Most occur inside other foraminiferal tests, which they apparently occupy after the death of the host organism. There is a preference for coarsely agglutinated fragments of other primitive agglutinated foraminifera. Such a preference suggests a detritivore feeding strategy, perhaps taking advantage of some residual organic matter (the organic cement) that was preserved between the grains of the host agglutinated foraminifer. The attached species Ammolagena clavata (Jones and Parker) also displays such a substrate preference [22]. By settling on biogenic particles, A. hemisphaericus sp. nov. may also be taking advantage of a bacterial flora that colonizes such grains and produces iron-manganese staining of the dead foraminiferal tests. An association between 


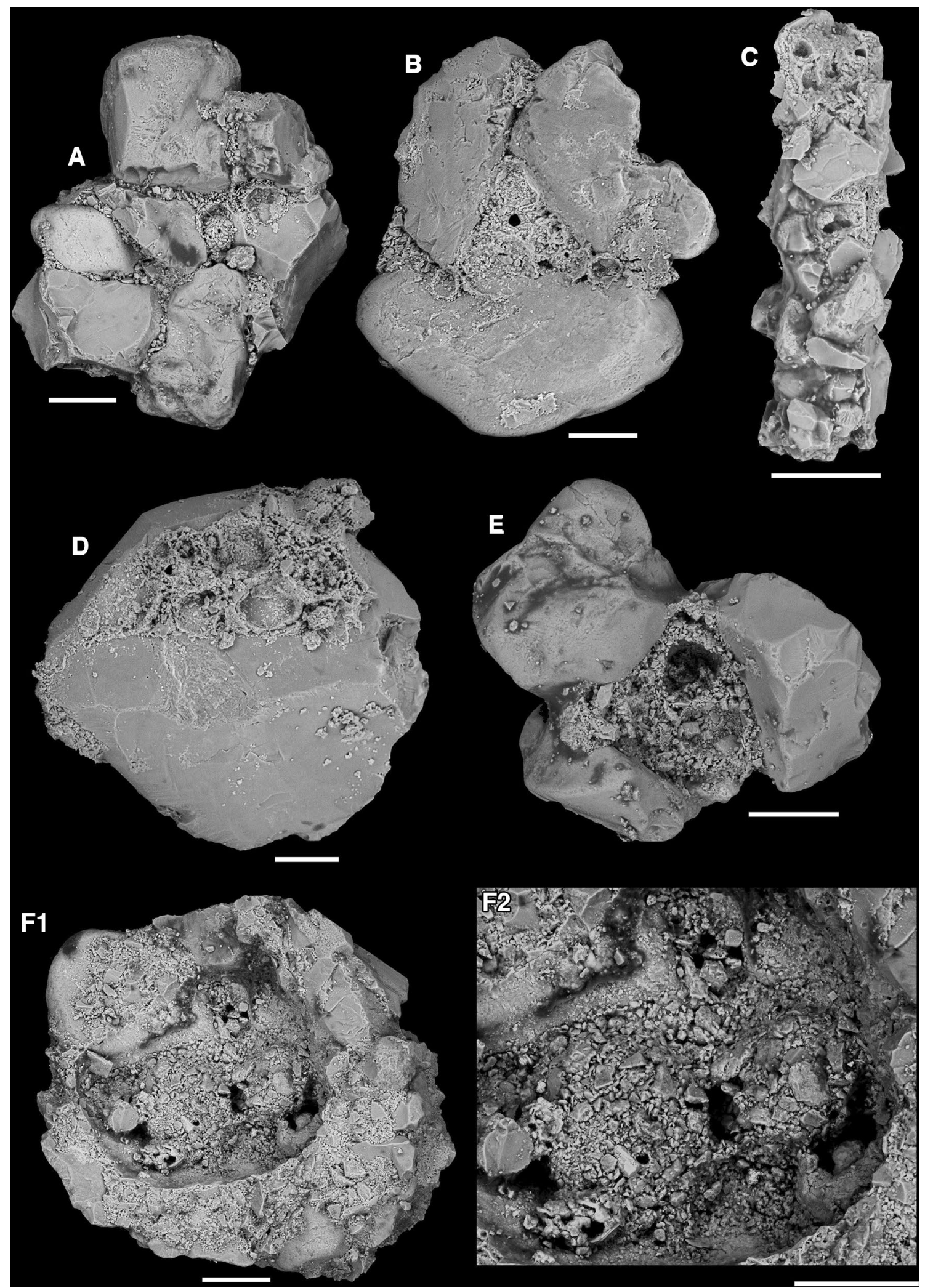

iron-manganese reducing bacteria and foraminifera that occupy the interior of foraminiferal tests has been noted by Gooday and Haynes [8] in the North Atlantic. Many of the specimens of agglutinated foraminifera from the Pleistocene of the Lomonosov Ridge are encrusted by an ironmanganese coating. This dark coating is especially well 
४Fig.4 Paratype specimens of Ammopemphix hemisphaericus sp. nov. a Ammopemphix hemisphaericus sp. nov. on the internal surface of a coarsely agglutinated bioclast (Core PS87/30 476-478 cm), b Ammopemphix hemisphaericus sp. nov. specimens on the internal surface of an agglutinated bioclast (Core PS87/30 302-304 cm), c Ammopemphix hemisphaericus sp. nov. inside a specimen of Psammosiphonella sp. (Core PS87/30 536-538 cm), d Ammopemphix hemisphaericus sp. nov. occupying a surface depression on the surface of a quartz grain (Core PS87/30 278-279 cm), e Ammopemphix hemisphaericus sp. nov. between some quartz grains (Core PS87/30 536$538 \mathrm{~cm})$, f Ammopemphix hemisphaericus sp. nov. on the internal surface of a chamber of Hormosina sp. (Core PS87/30 404-406 cm). Scale bar $=100 \mu \mathrm{m}$

developed on specimens of Reticulophragmium pusillum and Haplophragmoides arcticus, but it can also occur between the grains of the coarsely agglutinated fragments that are colonized by A. hemisphaericus sp. nov.

The glacial environment of the Arctic Ocean must have been difficult for the development of normal marine faunas. The cold temperatures and extremely oligotrophic conditions caused by the thick permanent ice cover must have presented a barrier for certain benthic organisms, and fostered a benthic fauna that is much reduced in terms of both abundance and number of species. The opportunistic species that were able to exist in such a restricted environment, such as A. hemisphaericus sp. nov., apparently took advantage of marginal food resources such as the organic matter preserved in empty foraminiferal tests or in the intergranular spaces within the wall of dead agglutinated foraminifera.

\section{The taxonomical status of Ammopemphix}

One of the diagnostic features of the genus Ammopemphix is its ability to construct a test that appears "multichambered", as pointed out in the description of Ammopemphix lacustris by Haman \& Marolt [10]. In his description of Urnula arctica, Cushman [3] stated that "chambers are apparently in communication with one another", even though Cushman's illustrations do not suggest there is any such connection between chambers. Loeblich and Tappan [16] mentioned in their description of the genus that "usually symmetrically arranged, with few chambers in single whorl, or with outer ring of chambers", which implies a certain mode of coiling. Therefore there has been some confusion in the literature concerning its unilocular vs. multilocular status.

In our opinion, the genus is better described as being monothalamous and pseudocolonial as pointed out by Haynes [11], who regarded the genus to be a synonym of the Paleozoic (Silurian) genus Colonammina. Haman \& Marolt [10] and Loeblich \& Tappan [17] did not uphold this proposed synonymy on the grounds that Colonammina is only known from the Paleozoic. Haman \& Marolt [10] did regard Ammopemphix to be pseudocolonial, describing it as "a random agglomeration of single chambers". These authors added that "any test symmetry or appearance of growth habit we believe to be purely fortuitous". In an emendation of the description of the species Haman [9] changed the description to "unilocular". In our view, a revised description of the genus needs to emphasise its monothalamous and pseudocolonial nature.

Two previously described species of Ammopemphix, A. arctica (Cushman 1948a) and A. quadrupla (Wiesner, 1931), both consist of individuals that are arranged in a regular manner: they are of nearly identical dimensions, are symmetrical about a central point, and they occur in fours or multiples of four [3, 15, 17, 24]. Adjacent individuals share a straight suture between them. As a result, the pseudocolonies appear to have a radial symmetry. In our material from the Lomonosov Ridge, such an arrangement of the tests has been observed, but is rare and limited to specimens of approximately equal dimensions. Wiesner [24] did not mention symmetry in his original definition of his genus Urnula - this feature seems to have been introduced into the description by Loeblich and Tappan [16]. Our specimens from the Lomonosov Ridge consist of individuals of different sizes, and these are not neccessarily arranged on the substrate with any sense of symmetry. The fact that the tests may be irregularly arranged, means that the statement about symmetry in the current description of the genus needs to be modified. We therefore propose the following emended description of the genus Ammopemphix:

Genus Ammopemphix Loeblich, 1952

Type species: Urnula quadrupla Wiesner, 1931

Synonyms.

Ammopemphix Loeblich, 1952, p. 82 (nom. subst. pro Urnula Wiesner, 1931).

Urnula Wiesner, 1931, p. 82 (non Urnula Claparede \& Lachmann, 1857).

Description Test attached, monothalamous, pseudocolonial. Chamber hemispherical, individual tests are nearly circular in outline; when attached to one another or hidden in a crevice, their shape may be rounded-polygonal in outline or conform to their substrate. Adjacent tests may be separated by a straight suture between them. Wall finely agglutinated, white to yellowish in colour, smoothly finished, attachment wall thin, delicate, and translucent. Aperture a single small, rounded opening at the apex of each test, may possess a collar or finely agglutinated rim. Pleistocene-Holocene; Antarctic: Arctic.

Remarks Ammopemphix is much like the attached forms of the genus Sorosphaera, (e.g., Sorosphaera depressa Heron-Allen and Earland) differing in possessing a terminal aperture on top of each chamber. The type species seems to display a type of radial symmetry, often consisting of four tests, with sutures between each test radiating outward from a central point like on a hot-cross bun. However, other 

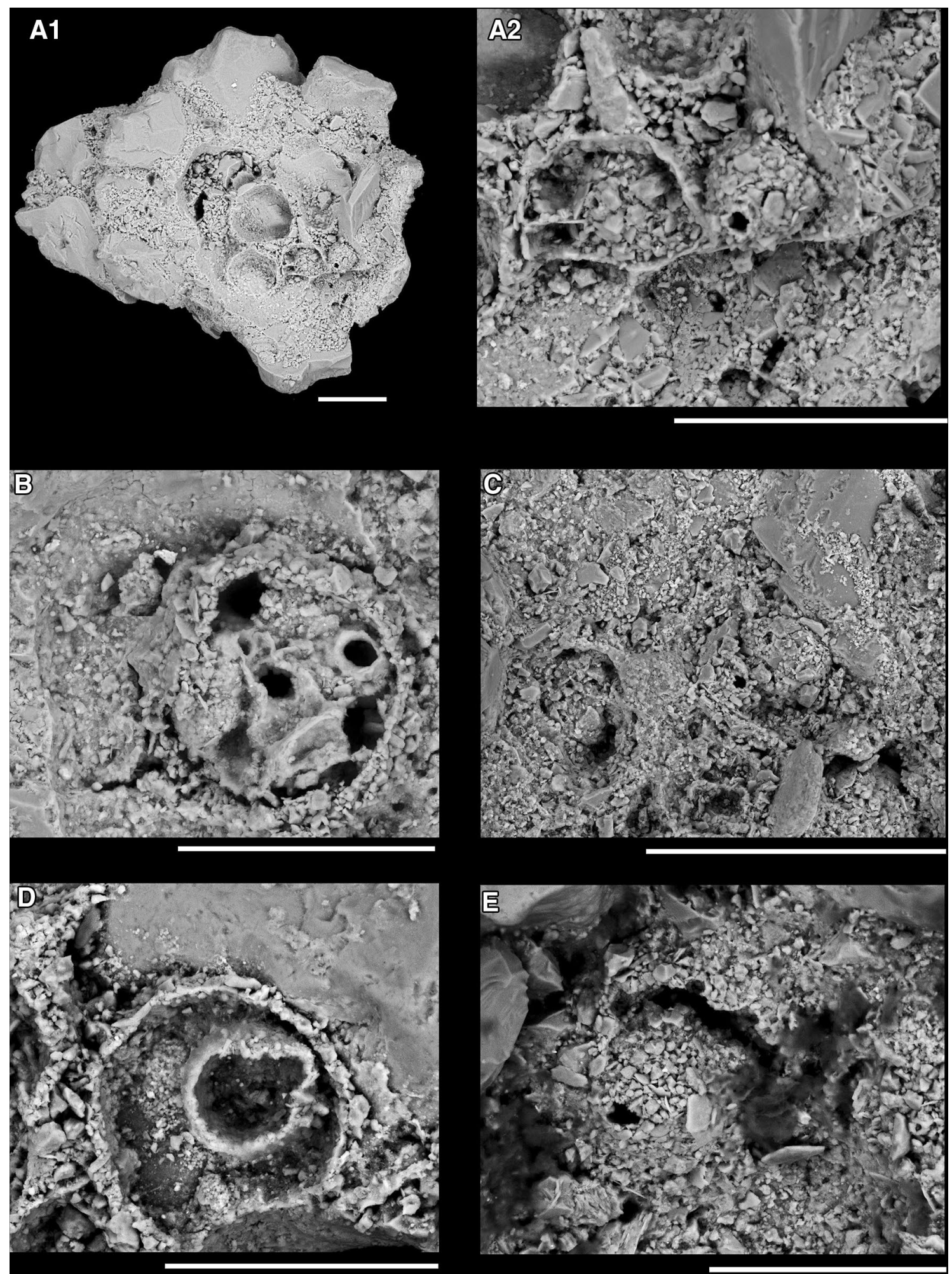

Fig. 5 Paratype specimens of Ammopemphix hemisphaericus sp. nov. a1 several Ammopemphix hemisphaericus nov. sp. on the internal surface of an agglutinated bioclast (Core PS87/30 295-297 cm), showing more than one generation of specimens, a2 a small unbroken specimen wedged into a crevice between grains, b Ammopemphix hemisphaericus sp. nov., three small specimens occupying the interior of a larger broken specimen (Core PS87/30 536-538 cm), c Ammopemphix hemisphaericus sp. nov. (Core PS87/30 278-279 cm), d Ammopemphix hemisphaericus sp. nov., a smaller specimen nestled inside a larger one (Core PS87/30 536-538 cm), e Ammopemphix hemisphaericus sp. nov., (Core PS87/30 583-585 cm). Scale bar $=100 \mu \mathrm{m}$ 
species of Ammopemphix display a more irregular arrangement. Three species of Ammopemphix have been decribed to date

Ammopemphix arctica (Cushman, 1948a), Ammopemphix quadrupla (Wiesner, 1931), and A. hemisphaericus sp. nov. A fourth unnamed species was illustrated by Barbosa et al. [1] from a Brazilian mangrove environment, which might be better assigned to the genus Lacustrinella Loeblich and Tappan, 1987. Haman and Marolt [10] described the species Ammopemphix lacustris from the Lac des Allemands on the Mississippi Delta. Loeblich and Tappan [17] designated it the type species of their new genus Lacustrinella, which was reported to differ from Ammopemphix in possessing a more inflated test and a more prominent and elevated aperture. In their remarks to Lacustrinella, Loeblich and Tappan mentioned that Ammopemphix is more flattened and has a wholly organic membrane (lacks an agglutinated wall) on the attachment surface. Our specimens from the Arctic do not show these features. We follow the suggestion by Loeblich and Tappan and separate the genera based on their ecological preferences, as Lacustrinella only occurs in brackish shallow-water subtropical environments. Future investigations of the molecular biology of living specimens may ultimately resolve the issue of synonymy. The validity of Lacustrinella was upheld by Haman [9], who provided an updated description of the type species regarding it as unilocular, not multilocular.

Wiesner [24] described the type species from a single station, $385 \mathrm{~m}$ depth, off Antarctica. The test wall as comprised of sand and mica flakes. Ammopemphix is known mostly from polar regions of the northern and southern hemisphere, and until now has only been reported from modern sediments [e.g., 3, 4, 15, 17-20, 23, 24]. The genus has also been reported from Brazilian mangroves [1], and from the Ria de Vigo on the northwestern Iberian margin [5]. Our finding is the first report of the genus from the Pleistocene.

\section{Conclusions}

The new species $A$. hemisphaericus sp. nov. is described from mid-Pleistocene sediments from the Lomonosov Ridge in the Central Arctic Ocean. The species forms pseudocolonies that are often found in the inner surface of empty agglutinated foraminiferal tests and more rarely on inorganic sediment particles. The definition of the genus Ammopemphix is here modified taking into account the morphological characteristics of the new species.

Acknowledgements A.W. thanks AGH statutory funds Grant No. 11.11.140.005. MAK thanks Prof. Rudiger Stein (AWI) for the opportunity to participate on the ALEX Expedition (PS87-ARK-XXVIII/4); as well as the Deans of the Science Faculty and the College of Petroleum Engineering and Geosciences (CPG), KFUPM for funding shipboard participation on Expedition PS87, and the current research from CPG start-up funds. The manuscript benefitted from comments by Jaroslaw Tyszka and two anonymous reviewers. We thank the Micropress Europe Foundation for logistical support by housing the type specimens.

Sample availability Microscope slides are deposited in the European Micropalaeontological Reference Centre, Micropress Europe, al. Mickiewicza 30, Kraków, Poland. Viewing is by appointment during working hours.

Author contributions AW made SEM photos and plates; MAK took part in the PS87 Expedition and collected and prepared samples; Both authors jointly wrote the manuscript.

\section{Compliance with ethical standards}

Conflict of interest Both authors declare no conflict of interest.

Open Access This article is distributed under the terms of the Creative Commons Attribution 4.0 International License (http://creativeco mmons.org/licenses/by/4.0/), which permits unrestricted use, distribution, and reproduction in any medium, provided you give appropriate credit to the original author(s) and the source, provide a link to the Creative Commons license, and indicate if changes were made.

\section{References}

1. Borbosa CF, Scott DB, Seoane JCS, Turcq BJ (2005) Foraminiferal zonations as baselines for quaternary sea-level fluctuations in south-southeast Brazilian mangroves and marshes. J Foramin Res 35:22-43

2. Cronin TM, Cronin MA (2015) Biological response to climate change in the Arctic Ocean: the view from the past. Arctos 1:4-18. https://doi.org/10.1007/s41063-015-0019-3

3. Cushman JA (1948) Arctic Foraminifera. Cushman Lab Foraminifer Res Spec Publ 23:1-79

4. Cushman JA (1948) Foraminifera, their classification and economic use. Harvard University Press, Cambridge, pp 605

5. Diz P, Frances G, Costas S, Souto C, Alejo I (2004) Distribution of benthic foraminifera in coarse sediments, Ria de Vigo, NW Iberian Margin. J Foramin Res 34:258-275

6. Evans JR, Kaminski MA (1998) Pliocene and Pleistocene chronostratigraphy and palaeoenvironment of the Central Arctic Ocean, using deep water agglutinated foraminifera. Micropaleontology 44:109-130

7. Evans JR, Kaminski MA, Cronin TM.,Fütterer DK (1995) Pleistocene agglutinated foraminifera from the Lomonosov Ridge and Amundsen Basin, Arctic Basin. Initial report on position cores 2177-5 (KAL) and 2176-3 (KAL). Mar Micropaleontol 26:245-253

8. Gooday AJ, Haynes JR (1983) Abyssal foraminifers, including two new genera, encrusting the interior of Bathisiphon rusticus tubes. Deep Sea Res 30:591-614

9. Haman D, Marolt RE (1985) Ammopemphix lacustris n.sp. (Foraminiferida) from Lac Des Allemands, Louisiana. Tulane stud Geol Paleontol 18:157-159

10. Haman D (1989) Ontogeny and morphological variability of the foraminiferid Lacustrinella lacustris (Haman and Marolt). Micropaleontology 35:375-378

11. Haynes JR (1981) Foraminifera. MacMillan, London, pp 433 
12. Kaboth S, Kaminski MA, Nam S, Zwick M, De Vernal A (2014) Micropaleontology and Biostratigraphy. In: Stein R (ed) ARKXXVII/4, 05 August-08 October, 2014. Unpublished Cruise Report, Alfred Wegener Institute, Bremerhaven, pp 147-160

13. Kaminski MA, Waśkowska A (2017) Reticulophragmium pusillum assemblages from the Middle Pleistocene of the Central Arctic Ocean-preliminary results. In: The Micropaleontological Society Annual Conference, London, England, 15-16 Nov 2017

14. Loeblich AR (1952) Ammopemphis, new name for the recent foraminifera genus Urnula Wiesner. J Wash Acad Sci 43:82

15. Loeblich AR, Tappan H (1952) Studies of Arctic foraminifera. Smithson Misc Collect 121:1-150

16. Loeblich AR, Tappan H (1964) Sarcodina chiefly "Thecamoebians" and Foraminiferida. In: Moore RC (ed) Treatise on invertebrate paleontology, part C, Protista. University of Kansas Press, Lawrence, pp 900

17. Loeblich AR, Tappan H (1987) Foraminiferal genera and their classification. Van Nostrand Reinhold, New York, pp 970

18. Majewski W (2010) Benthic foraminifera from West Antarctic fiord environments: An overview. Pol Polar Res 31:61-82

19. Majewski W (2005) Benthic foraminiferal communities: distribution and ecology in Admiralty Bay, King George Island, West Antarctica. Pol Polar Res 26:159-214
20. Siciński J, Jażdżewski K, De Broyer C, Presler P, Ligowski R, Nonato EF, Corbisier TN, Petti MAV, Brito TAS, Lavrado HP, Błażewicz-Paszkowycz M, Pabis K, Jażdżewska A, Campos LS (2011) Admiralty Bay Benthos diversity - a census of a complex polar ecosystem. Deep Sea Res Part II 58:30-48

21. Stein R, Forwick M, Niessen F (2014) Lithostratigraphy and chronology of PS87 sediment cores: preliminary results. In: Stein R (ed) ARK-XXVII/4, 05 August-08 October, 2014. Unpublished cruise report, Alfred Wegener Institute, Bremerhaven, pp 125-143

22. Waśkowska A (2014) Distribution of the agglutinated foraminifer Ammolagena clavata (Jones and Parker) in Western Tethyan Upper Cretaceous and Paleogene deep-water deposits (Outer Carpathians, Poland). Micropaleontology 60:77-88

23. Wollenburg J (1995) Benthische Foraminiferenfauna als Wassermasses-, Produktions- und Eisdriftanzeiger im Arktischen Ozean. Berichte zur Polarforschung, 179, Alfred Wegener Institute for Polar and Marine Research, Bremerhaven, pp 1-227

24. Wiesner H (1931) Die Foraminiferen der Deutsche SüdpolarExpedition 1901-1903. Deutsche Südpolar-Exped 20:53-165 